\title{
PENGUKURAN KECERNAAN LEMAK KASAR, BAHAN ORGANIK DAN ENERGI PADA PAKAN IKAN NILA (Oreochromis niloticus) DENGAN MENGGUNAKAN TEKNIK PEMBEDAHAN
}

\section{MEASUREMENTS OF EXTRACT ETHER DIGESTIBILITY, ORGANIC MATTER AND ENERGY FEED IN TILAPIA (Oreochromis niloticus) USING SURGERY TECHNIQUES}

\author{
Rahardian Wicaksono, Agustono dan Widya Paramita Lokapirnasari \\ Fakultas Perikanan dan Kelautan Universitas Airlangga \\ Kampus C Mulyorejo - Surabaya, 60115 Telp. 031-5911451
}

\begin{abstract}
Tilapia is a freshwater fish species are widely cultivated in Indonesia. Tilapia production continues to grow every year, the average increase in the number of experienced production tilapia reaches $22.24 \%$ in the 2010-2011 range. Tilapia production in 2011 reached 567.449 tons and was second aquaculture production by major commodity after seaweed.

This study aimed to determining differences in extract ether digestibility, organic matter, and energy on feed derived from different factories in tilapia (Oreochromis niloticus) using surgery techniques. The research design is using completely randomized design. The variables were measured extract ether digestibility, organic matter, and energy in tilapia feed. Analysis of the data processed using Analysis of Variance (ANOVA) to determine differences in treatment given. If there is a difference then followed by Duncan's Multiple Range Test with a significance level of 5\%.

Based on the findings that there were no significant differences $(p>0.05)$ in extract ether , organic matter, and energy digestibility of the feed value of tilapia. The results stated that the feed treatments $\mathrm{A}, \mathrm{B}$ and $\mathrm{C}$ efficiently digested by tilapia.
\end{abstract}

Keywords : digestibility, extract ether, organic matter, energy, commercial feed

\section{Pendahuluan}

Ikan nila merupakan salah satu jenis ikan air tawar yang banyak dibudidayakan di Indonesia. Produksi ikan nila terus bertambah setiap tahun, kenaikan rata-rata jumlah produksi yang dialami ikan nila mencapai $22,24 \%$ pada rentang tahun 2010-2011. Tahun 2011 produksi ikan nila mencapai 567.449 ton dan berada di urutan kedua produksi perikanan budidaya menurut komoditas utama setelah rumput laut (PERMEN KKP No. PER.15/MEN/2012, 2012).

Pakan memegang peranan yang cukup penting pada budidaya ikan. Pakan buatan adalah pakan yang dibuat dengan formulasi tertentu berdasarkan pertimbangan kebutuhannya (Handajani dan Widodo, 2010). Faktor pakan menentukan biaya produksi mencapai 60-70 \% dalam usaha budidaya ikan, oleh karena itu diperlukan pengelolaan yang efektif dan efisien (Handajani, 2008). Pemberian pakan buatan dalam budidaya ikan, hasil produksi dapat dinaikkan hingga dua kali lipat dari produktifitas semula (Soeseno, 1984).

Nilai gizi pakan tergantung pada jumlah ketersediaan zat-zat makanan yang digunakan oleh ikan, yang ditunjukkan dari bagian yang hilang setelah pencernaan, penyerapan, dan metabolisme. Cara mengukur ketersediaan zat-zat makanan bagi tubuh tersebut adalah melalui penentuan kecernaan (Cho et al., 1985).

Kecernaan suatu bahan pakan merupakan pencerminan dari tinggi rendahnya nilai manfaat dari bahan pakan tersebut (Ranjhan, 1997 dalam Pertiwi 2011). Informasi tentang nilai kecernaan suatu bahan makanan atau suatu makanan sangat penting sebagai dasar dalam menilai mutu makanan dan dalam merancang ransum, disamping nilai kecernaan dapat menggambarkan kemampuan ikan dan kualitas bahan makanan yang dikonsumsi oleh ikan (Handajani dan Widodo, 2010).

\section{Metodologi}

Penelitian pendahuluan dilakukan untuk mengetahui jumlah feses dengan jumlah terbanyak yang terdapat pada usus besar hingga anus. Penelitian pendahuluan ini diberikan perlakuan perbedaan waktu untuk mengetahui jumlah feses yang terkumpul paling banyak, Yaitu 1 jam, 3 jam, 5 jam, dan 7 jam, kemudian didapatkan hasil dengan jumlah feses terbanyak 
Tabel 1. Hasil uji pendahuluan terhadap ikan nila

\begin{tabular}{|l|c|c|c|c|c|}
\hline No. & Perlakuan & $\begin{array}{c}\text { Berat Ikan } \\
(\mathrm{g})\end{array}$ & $\begin{array}{c}\text { Panjang } \\
\text { Ikan } \\
(\mathrm{cm})\end{array}$ & $\begin{array}{c}\text { Feses } \\
\text { Berat Basah } \\
(\mathrm{g})\end{array}$ & $\begin{array}{c}\text { Feses } \\
\text { Berat Kering }(\mathrm{g})\end{array}$ \\
\hline 1. & A1 = 1 Jam & 116 & 21 & 1 & 0,6 \\
2. & A2 = 3 Jam & 87,5 & 16,5 & 2 & 1,4 \\
3. & A3 = 5 Jam & 102,5 & 17,5 & 2,5 & 2 \\
4. & A4 = 7 Jam & 82,5 & 17 & 2,4 & 1,7 \\
\hline
\end{tabular}

yang terdapat pada usus besar adalah 5 jam setelah pemberian pakan perlakuan.

Penelitian ini dimulai dari persiapan peralatan dengan membersihkan alat yang akan digunakan. Aquarium sebelum digunakan sebagai tempat pemeliharaan dilakukan sterilisasi untuk menghilangkan mikroba yang ada pada aquarium tersebut. Media pemeliharaan yang akan digunakan adalah air tawar yang diendapkan dan diaerasi terlebih dahulu sebelum digunakan. Sebelum ikan ditebar pada kolam, ikan diaklimatisasi terlebih dahulu selama 30 menit. Pakan uji yang digunakan adalah pakan buatan berbentuk pelet kering. Pakan diberikan tiga kali sehari sesuai tahap adaptasi, ikan dipelihara dan diberi pakan percobaan selama 7 hari.

Ikan diadaptasi selama 7 hari untuk membiasakan ikan terhadap pakan uji. Pakan diberikan dengan frekuensi tiga kali sehari sesuai dengan tahap adaptasi sebanyak 5\% dari biomassa ikan. Hari ke- 8 ikan diberi pakan satu kali pada pagi hari kemudian puasa selama 24 jam untuk melakukan pengosongan lambung. Hari ke-9 ikan setelah puasa diberi pakan sampai ikan kenyang (adlibitum), 5 jam kemudian ikan dibunuh dengan tujuan menghentikan aktifitas dan dilanjutkan dengan pembedahan untuk mengambil feses di bagian usus besar. Tujuan dari teknik pembedahan ini adalah sebagai salah satu cara untuk memperoleh feses di bagian usus supaya tidak sampai keluar dari anus dan bercampur dengan air pada kolam pemeliharaan.

Pengambilan feses pada jam ke-5 dilakukan menurut uji pendahuluan yaitu feses yang terkumpul paling banyak di bagian usus terdapat pada 5 jam setelah pemberian pakan. Teknik pembedahan tidak dapat dilakukan pada saat itu karena terhalang oleh beberapa faktor yaitu waktu dan jumlah ikan, sehingga ikan akan disimpan di dalam frezer supaya kondisi bentuk dan warna feses tetap seperti kondisi segar. Pembedahan dilakukan setiap hari hingga ikan benar-benar habis.

Analisa proksimat merupakan
pengujian kimiawi untuk mengetahui kandungan nutrien suatu bahan baku pakan atau pakan. Metode analisa proksimat pertama kali dikembangkan oleh Henneberg dan Stohman pada tahun 1860 di sebuah laboratorium penelitian di Weende, Jerman (Hartadi et al., 1997). McDonald et al. (2002) menjelaskan bahwa analisa proksimat dibagi menjadi enam fraksi nutrien yaitu kadar air, abu, protein kasar, lemak kasar, serat kasar dan bahan ekstrak tanpa nitrogen (BETN). Setyono $d k k \quad$ (2009) menambahkan, pengurangan bahan kering dengan abu akan menghasilkan bahan organik. Perhitungan kecernaan lemak kasar, bahan organik, dan energi sebagai berikut:

a. Kecernaan Lemak Kasar $(\mathrm{KcLK})=$ KLK $(g)-$ LK feses (g) x $100 \%$ $\operatorname{KLK}(\mathrm{g})$

$\begin{aligned}- \text { KLK }= & \text { Konsumsi Pakan x } \% \\ & \text { LK Pakan } x \% \text { BK } \\ & \text { Pakan } \\ \text { - LK feses }(\mathrm{g})= & \% \text { LK feses } \mathrm{x} \text { gram } \\ & \text { feses (produksi feses) } \mathrm{x} \\ & \% \text { BK Pakan }\end{aligned}$

b. Kecernaan Bahan Organik $(\mathrm{KcBO})=$ $\underline{\mathrm{KBO}(\mathrm{g})-\mathrm{BO} \text { feses }(\mathrm{g}) \times 100 \%}$ $\mathrm{KBO}(\mathrm{g})$
- $\mathrm{KBO}=$ Konsumsi Pakan $\mathrm{x} \%$ BO Pakan x \% BK Pakan
- BO feses $(\mathrm{g})=\%$ BO feses $\mathrm{x}$ gram feses (produksi feses) $\mathrm{x}$ \% BK Pakan

c. Kecernaan Energi $(\mathrm{KcEn})=$ KEn (g) - En feses (g) x 100\%

$\begin{aligned} \text { KEn }(\mathrm{g}) & \\ = & \text { Konsumsi Pakan } \mathrm{x} \% \\ & \text { En Pakan } \mathrm{x} \% \mathrm{BK} \\ & \text { Pakan } \\ \text { - En feses }(\mathrm{g})= & \% \text { En feses } \mathrm{x} \text { gram } \\ & \text { feses (produksi feses) } \mathrm{x} \\ & \% \text { BK Pakan }\end{aligned}$

Keterangan :

KLK = Konsumsi Lemak Kasar

$\mathrm{KBO}=$ Konsumsi Bahan Organik 
$\mathrm{KEn}=$ Konsumsi Energi

KcLK = Kecernaan Lemak Kasar

$\mathrm{KcBO}=$ Kecernaan Bahan Organik

$\mathrm{KcEn}=$ Kecernaan Energi

\section{Hasil dan Pembahasan}

Berdasarkan hasil uji analisa proksimat dan perhitungan nilai kecernaan feses, menunjukkan bahwa pakan perlakuan ikan nila yang diberikan menunjukkan hasil tidak berbeda nyata $(\mathrm{p}>0,05)$, dengan demikian dapat disimpulkan bahwa tidak terdapat perbedaan nilai kecernaan lemak kasar, bahan organik, dan energi pada semua perlakuan. Data rata - rata nilai kecernaan lemak kasar dapat dilihat pada tabel 2, data rata - rata nilai kecernaan bahan organik dapat dilihat pada tabel 3, dan data rata - rata nilai kecernaan energi dapat dilihat pada tabel 4 .

Tabel 2. Rata-rata nilai kecernaan lemak kasar pada masing-masing perlakuan

\begin{tabular}{|c|c|c|}
\hline Perlakuan & $\begin{array}{c}\text { Nilai Kecernaan } \\
\text { Lemak Kasar } \\
\pm \text { SD }(\%)\end{array}$ & $\begin{array}{c}\text { Nilai } \\
\text { Transformasi } \\
\pm \text { SD }(\%)\end{array}$ \\
\hline A & $94,9255 \pm 1,34$ & $76,99 \pm 1,78$ \\
B & $95,5013 \pm 2,08$ & $77,84 \pm 1,87$ \\
C & $94,7873 \pm 1,54$ & $76,84 \pm 2,24$ \\
\hline
\end{tabular}

Tabel 3. Rata - rata nilai kecernaan bahan organik pada masing - masing perlakuan

\begin{tabular}{|c|c|c|}
\hline Perlakuan & $\begin{array}{c}\text { Nilai Kecernaan } \\
\text { Bahan Organik } \\
\pm \text { SD (\%) }\end{array}$ & $\begin{array}{c}\text { Nilai } \\
\text { Transformasi } \\
\pm \text { SD (\%) }\end{array}$ \\
\hline A & $96,2448 \pm 1,10$ & $78,865 \pm$ \\
& & 1,72 \\
B & $94,5717 \pm 1,70$ & $76,612 \pm$ \\
C & $94,8578 \pm 1,48$ & $76,94 \pm 1,85$ \\
\hline
\end{tabular}

Tabel 4. Rata-rata nilai kecernaan energi pada masing - masing perlakuan

\begin{tabular}{|c|c|c|}
\hline Perlakuan & $\begin{array}{c}\text { Nilai Kecernaan } \\
\text { Energi } \\
\pm \mathrm{SD}(\%)\end{array}$ & $\begin{array}{c}\text { Nilai } \\
\text { Transformasi } \\
\pm \mathrm{SD}(\%)\end{array}$ \\
\hline A & $96,9768 \pm 1,67$ & $80,0233 \pm 3,4$ \\
B & $91,5828 \pm 9,77$ & $74,735 \pm 8,86$ \\
C & $94,9949 \pm 1,55$ & $77,13 \pm 1,98$ \\
\hline
\end{tabular}

Hasil penelitian menunjukkan bahwa pemberian pakan komersil pada ikan nila tidak memberikan perbedaan yang nyata $(\mathrm{p}>0,05)$ terhadap nilai kecernaan lemak kasar. Nilai kecernaan lemak kasar pada tiga perlakuan adalah A $(94,9255 \%)$, B $(95,5013 \%)$, C $(94,7873 \%)$, namun demikian ketiga perlakuan menunjukkan nilai kecernaan yang tinggi, berkisar $\pm 90 \%$ pada tiap perlakuan. Hal ini didukung pula oleh Pond et al., (2005) bahwa sebagian zat makanan yang mengandung sumber-sumber lemak dalam jumlah energi berkaitan dengan kecernaan tubuh, pada kondisi normal daya cerna lemak yaitu melebihi $80 \%$. Ketiga pakan yang digunakan dalam penelitian ini memiliki kandungan lemak kasar yang tidak jauh berbeda, dimana nilai lemak kasar pada pakan perlakuan menunjukkan hasil analisa proksimat sebagai berikut : pakan A (7, 4724 $\%)$, pakan B $(9,6605 \%)$, pakan C $(9,2934 \%)$. Hal ini sesuai dengan standar SNI 01-72422006 yang mengatur standar minimal kadar lemak kasar dalam pakan buatan yaitu minimal $5 \%$, sehingga memberikan hasil yang tidak jauh berbeda pada nilai kecernan.

Hasil penelitian yang dilakukan terhadap tiga jenis pakan dari produksi yang berbeda terhadap kecernaan bahan organik pakan ikan nila menunjukkan tidak terdapat perbedaan yang nyata $(\mathrm{p}>0,05)$, dimana kandungan bahan organik pada pakan A (96, $2448 \%), \mathrm{C}(94,8578 \%)$, dan B $(94,5717 \%)$ memberikan hasil yang sama baik. Secara umum daya cerna bahan organik dipengaruhi oleh spesies hewan, umur hewan, dan nilai bahan pakan (Ranjhan, 1981). Spesies ikan pada penelitian ini adalah sama begitu pula dengan umur ikan dan nilai bahan pakan pada masingmasing jenis pakan yang berbeda tidak terdapat perbedaan yang mencolok.

Hasil penelitian yang telah dilakukan terhadap tiga jenis pakan dari produksi yang berbeda terhadap kecernaan energi pakan ikan nila menunjukkan tidak terdapat perbedaan yang nyata. Nilai kecernaan energi pada masing-masing perlakuan adalah sebagai berikut : A ( 96, $9768 \%$ ), C ( 94,9949\%), dan B $(91,5828 \%)$, hal ini menyebabkan hasil kecernaan feses pada ikan nila tidak berbeda nyata $(\mathrm{p}>0,05)$. Ikan mendapatkan energi dari pakan yang dikonsumsi dengan kandungan bahan yang dibutuhkan seperti protein, lemak, dan karbohidrat sebagai sumber energi. Kebutuhan energi dalam pakan diusahakan dalam keadaan seimbang, kekurangan dan kelebihan energi dalam pakan dapat menurunkan pertumbuhan ikan (Sukoso, 2002). Faktor utama yang mempengaruhi kebutuhan energi ikan antara lain spesies ikan, pertumbuhan, ukuran, umur, aktivitas biologis, 
suhu, dan tipe makanan (Hariati, 1990 dalam Sari, 2009).

Menurut Hatmaya (2008), kecernaan bahan pakan dapat dipengaruhi oleh beberapa faktor, diantaranya komposisi ransum, bentuk fisik bahan pakan, faktor keragaman antar individu, jumlah pakan, bentuk fisik makanan dan suhu udara.

\section{Kesimpulan}

Berdasarkan penelitian yang telah dilakukan tentang pengukuran kecernaan lemak kasar, bahan organik, dan energi pada pakan ikan nila (Oreochromis niloticus) dengan menggunakan teknik pembedahan, maka dapat disimpulkan bahwa tidak terdapat perbedaan yang nyata terhadap kecernaan lemak kasar, bahan organik, dan energi pada pemberian pakan yang berbeda terhadap ikan nila (Oreochromis niloticus).

\section{Daftar Pustaka}

Cho, C.Y., C.B. Cowey, and R. Watanabe. 1985. Finfish Nutrition in Asia: Methodological approaches research Centre. Ottawa. pp 154.

Handajani, H. 2008. Pengujian Tepung Azolla Terfermentasi Sebagai Penyusun Pakan Ikan Terhadap Pertumbuhan dan Daya Cerna Ikan Nila Gift. Naskah Publikasi. Fakultas Peternakan Perikanan. Universitas Muhammadiyah. Malang.

Hartadi H., S. Reksohadiprojo, AD. Tilman. 1997. Tabel Komposisi Pakan Untuk Indonesia. Cetakan Keempat, Gadjah Mada Uivesity Press, Yogyakarta.

Hatmaya, R.T. 2008. Efek Berbagai Pakan Komplit Terhadap Daya Cerna Lemak Kasar dan Serat Kasar Pada Sapi Perah. Skripsi. Fakultas Kedokteran Hewan. Universitas Airlangga. Surabaya.

Mc Donald, P., R.A. Edwards, J.F.G Greenhalgh, and C.A. Morgan. 2002. Animal Nutrition. Dalam : Priambada, N.P. 2009. Kecernaan Serat Kasar Pada Babirusa (Babirousa babirussa) yang Diberi Pakan Kangkung dan Ketela di Kebun Binatang Surabaya (KBS). Skripsi. Fakultas Kedokteran Hewan. Universitas Airlangga. Surabaya.

Peraturan Menteri Kelautan dan Perikanan no. 15/ PER.15/MEN/2012. 2012. Jakarta.

Pond, W.G., D.C. Church, K.R. Pond, and P.A. Schocknecht. 2005. Basic Animal
Nutrition and Feeding. Fifth Ed. John Wiley and Sons, Inc. United States.

Ranjhan, S.K. 1981. Animal Nutrition In Tropics. 2nd Ed. Vikas Publishing House PUT Ltd. New Delhi.

Ranjhan, S. K. 1997. Animal Nutrition and Feeding Practices. Fourth Ed. Vikas Publishing House PVT LTD. New Delhi. dalam : Pertiwi, N. A. 2011. Nilai Kecernaan Lemak Kasar Berbagai Jenis Pakan Komplit pada Kambing Peranakan ETAWA. Skripsi. Fakultas Kedokteran Hewan. Universitas. Airlangga. Surabaya. Hal 83-106.

Sari, W.P. 2009. Pemberian Pakan Dengan Energi Yang Berbeda Terhadap Pertumbuhan Benih Ikan Kerapu Tikus (Chromileptes altivelis). Skripsi. Fakultas Perikanan dan Kelautan. Universitas Airlangga. Surabaya.

Setyono, H., Kusriningrim, Mustikoweni, T. Nurhajati, R.Sidik, Agustono, M.A. Al Arif, M. Lamid, A. Monica, dan W. Paramita. 2009. Teknologi Pakan Hewan. Fakultas Kedokteran Hewan. Universitas Airlangga. Surabaya.

Soeseno, S. 1984. Dasar - Dasar Perikanan Umum, Untuk Sekolah Pertanian Pembangunan. CV. Yasaguna. Jakarta. Hal $23-25$. 